\title{
Current Status of Sludge Collection, Transportation and Treatment in Ho Chi Minh City
}

\author{
Nguyen Trung Viet, Tran Thi My Dieu, Nguyen Thi Phuong Loan \\ Department of Environmental Management and Technology, Van Lang University, Ho Chi Minh City, Vietnam. \\ Email: tvtvhv763@yahoo.com, tranthimydieu@vanlanguni.edu.vn
}

Received February 20 ${ }^{\text {th }}, 2013$; revised March 25 ${ }^{\text {th }}, 2013$; accepted April 21 ${ }^{\text {st }}, 2013$

Copyright (C) 2013 Nguyen Trung Viet et al. This is an open access article distributed under the Creative Commons Attribution License, which permits unrestricted use, distribution, and reproduction in any medium, provided the original work is properly cited. In accordance of the Creative Commons Attribution License all Copyrights (C) 2013 are reserved for SCIRP and the owner of the intellectual property Nguyen Trung Viet et al. All Copyright (C) 2013 are guarded by law and by SCIRP as a guardian.

\begin{abstract}
In the process of construction and development, Ho Chi Minh City is discharging about six types of sludge: 1) sludge from urban wastewater drainage systems; 2) sludge from industrial wastewater drainage system; 3) sludge from the canal dredging activities periodically; 4) sludge from septic tanks; 5) sludge from the water treatment station/plant; 6) sludge from the construction sites. Sludge's components are very different among types of sludge, sludge from the sewer network and canal dredging contain mainly sand and soil (70\% - 90\% dry weight), while the sludge from the wastewater/water treatment station/plant and from septic tanks contain mainly biodegradable organic substances (55\% $80 \%$ dry weight). The concentrations of all above-mentioned sludge (except sludge from the hazardous industrial wastewater treatment plant) are lower than toxic threshold. The volume of total sludge is about $3000-4000 \mathrm{~m}^{3} / \mathrm{day}$ (5000 - 6000 tons/day), excepting the amount of sludge generated from the water treatment plant (which is collected and treated separately). Sludge from wastewater treatment plants and septic tanks is collected, transported and recycled to become organic fertilizer. The other types of sludge are collected, transported, and disposed at the "unknown” locations, even though they have different values for use.
\end{abstract}

Keywords: Sludge; Sludge Collection; Sludge Transportation; Sludge Treatment; Sludge Management

\section{Introduction}

Ho Chi Minh City (HCMC) is the special city; large center of economic, cultural, education and training, and science and technology; this is an important political position of the country; and this also is an international exchange hub, industrial central, and multi-disciplinary services of the region and South East Asia. HCMC has an area of $2095 \mathrm{~km}^{2}$ and a population of (registered residents and visitors) more than 9 million people (2011); moreover, HCMC located in the most dynamic economic regions of Vietnam, including the Mekong Delta and the southeastern region including the southern key economic region (including Ho Chi Minh city, Dong Nai and Ba Ria-Vung Tau, Binh Duong, Binh Phuoc, Tay Ninh, Long An, and Tien Giang). HCMC is the heading economic city not only in the region but also in the whole country. In 2011, the city's GDP reached 10.3\%, which is 1.75 times higher than the national average. Total GDP per capita in the city in 2011 was $\$ 3220$ and the city con- tributed $22.5 \%$ of the national budget, $30 \%$ of GDP, and $30 \%$ of the total social investment of Vietnam.

In addition to producing a large volume of products for domestic and export demand, HCMC also consumes a huge amount of natural resources (renewable and nonrenewable) and energy (54 million $\mathrm{kWh} /$ day, nearly 14,000 tons of fuel and thousands of tons of coal/day), and releases into the environment a corresponding volume (more than 2 million tons/day) of waste (gas, liquid, solid and sludge) including non-hazardous waste and hazardous waste; the waste can be recycled and nonrecyclable. Environment and quality of life are diminished because of the lack of sustainability (using resources and energy inefficiency) and by the several types of waste.

Among above mentioned wastes, municipal solid wastes are the greatest concern to many environmental hazards. National Environmental Report 2011 on Solid waste was issued by Ministry of Natural Resources and Environment announced in July 2012 presented the urgency of 
this problem. Solid waste management is one of the major problems, which appear frequently in the agenda of the world's climate change as well as group organizations of cities on climate change (The C40 Cities Climate Leadership Group-C40).

Meanwhile, the sludges also account for a relatively large volume of very different components which have not had adequate attention, or more precisely work of the state administration for this type of waste is not fully implemented; it can say almost loose due to many causes, as well as subjective. Over time and with the increasing demands on quality of life as well as environmental protection requirements of the city, the sludges are paid more attention due to their ability to pollute the environment and affect our urban landscape.

This report presents the situation (management) of collection, transport and treatment (recycling) of various sludges in HCMC, as well as future management orientation towards the highest recycling rate, green growth, and low carbon emissions.

\section{Current Status of Sludge Collection, Transportation and Treatment}

\subsection{Sludge Classification}

According to actual requirements, from 2003 to present (2012), the Department of Natural Resources and Environmental (DONRE) has managed (all or apart) the following types of waste:

1) Air pollutants (emissions);

2) Liquid waste (sewage), including domestic, sewage, industrial, and medical;

3) Solid waste, including:

- Municipal solid waste (MSW);

- Industrial solid waste (ISW);

- Medical solid waste;

- Construction and Demolition (C \& D) waste;

4) Hazardous waste (industrial waste, medical waste, MSW and C \& D waste).

Arising from the fact, the requirements for sludge management have been appeared in recent time; although so far, the concept of "sludge" is not defined in the legislation, including sort order by mass and the ability pollution from high to low: (1) sludge from urban wastewater drainage systems; (2) sludge from industrial wastewater drainage system; (3) sludge from the canal dredging activities periodically; (4) sludge from septic tanks; (5) sludge from the water treatment station/plant; (6) sludge from the construction sites; and 7) other sludges.

If sludge from urban wastewater drainage systems (1), sludge from septic tanks (4), and sludge from the water treatment station/plant (5) are homogeneous composition; sludge from industrial wastewater drainage system (2), sludge from the canal dredging activities periodically (3), sludge from the construction sites (6) are different depended on production sectors, or the location and depth of dredging, different values of treatment and reuse methods. The survey results showed very clearly this identification.

\subsubsection{Sources, Composition and Volume of Sludges}

Due to the nature of the sources, sludge collection and transportation, reuse, and treatment, especially the potential environmental pollution (pollution components, volume, and rate of spread) and due to insufficient management attention of the state administrative agencies, very few data on the composition and volume of sludge is collected and stored systematically. Department of Science and Technology is a state administrative body storing a lot of data on the types of sludge through scientific research reports from 2008 to present.

\subsubsection{Sludge from Urban Wastewater Drainage System}

Sludge from urban wastewater drainage systems generated from:

1) The city's wastewater drainage network, and

2) Dometic waste wastewater treatment plant.

Sludge from the wastewater drainage network of various levels (e.g., levels 2, 3 and 4) is generated as a result of dredging activities by Urban Drainage Limited Company (UDC) for network levels 2 and 3 (pipe diameter is $400 \mathrm{~mm}$ or more) and by Public Service Limited Company at districts - for network level 4 . The drainage network of HCMC is divided into four levels with a total length of over $9800 \mathrm{~km}$ and 65,000 manholes with different types.

According to the annual plan, the above mentioned companies clean up the wastewater drainage network and dredge the manholes periodically with sludge volume estimated as $1200-1500 \mathrm{~m}^{3} /$ day or $450,000-700,000$ $\mathrm{m}^{3} /$ year. In which, about $90 \%$ - $95 \%$ of the volume is collected in the dry season. This sludge consists mainly sand (70\% - 90\% dry weight) accumulated from wastewater and rainwater; however, this sludge also contains plastic, textile, cans, tins, etc. as municipal solid waste (Figure 1) because of low citizen's awareness. Amount of biodegradable organic matter in sludge is very low due to high solubility in wastewater as well as long stored time in sewage system ( 3 - 6 months or up to 12 months); therefore the sludge is drifted with wastewater flow in sewage system or is bio-decomposited. Sludge may contain hazardous wastes (such as heavy metals, oil and grease) depending on the location and dredging time; however, the concentration of these hazardous wastes is generally lower than the threshold of environmental standards. After preliminary treatment, the sludge can be used for leveling due to low quality (comtaminated by 

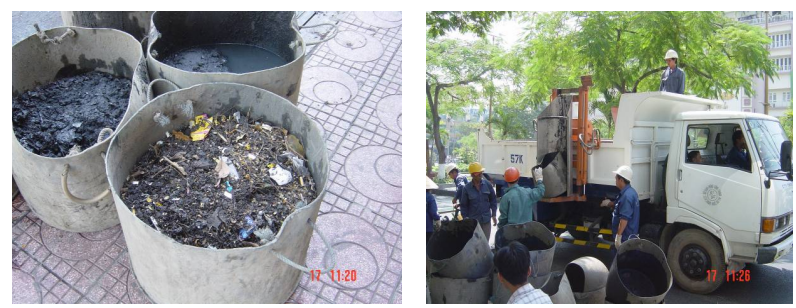

Figure 1. Sludge from dredging of wastewater drainage network.

impurities) and black color (FeS).

Currently, HCMC has only two urban wastewater treatment plants (which is mixed of domestic wasterwater, industrial wastewater, hotel and restaurant wastewater, wastewater from medical facilities, etc., including early stage's rainwater) including Binh Hung Hoa (capacity: 30,000 $\mathrm{m}^{3} /$ day) and Binh Hung (capacity: $141,000 \mathrm{~m}^{3} /$ day). According to the plan, in the near future, the city will have 7 - 9 concentrated treatment plants for different basins (09); the capacity of each treatment plant ranges from 100,000 to $500,000 \mathrm{~m}^{3} /$ day. Two above mentioned treatment plants are applied the aerobic activated sludge processes (Binh Hung Hoa: aerobic pond; Binh Hung: aerobic activated sludge with suspended growth); therefore the amount of sludge generated is quite much (Binh Hung 30\% - 40 tons wet weight/day). These two factories installed a sludge drying equipment (reduce moisture content to $30 \%-40 \%$ ). Organic matter content (volatile compounds-VS) of sludge accounts for $55 \%-80 \%$ dry weight and the concentration of toxic substances is often much lower than the threshold of environmental standards.

Besides, the city also has thousands of domestic wastewater treatment plants for the new residential areas, condominiums, hotels, restaurants, supermarkets, medical facilities (hospitals, health centers, clinic, etc.) with a capacity of few thousands $\mathrm{m}^{3} /$ day to several hundred thousands $\mathrm{m}^{3} /$ day. Most of the wastewater treatment plants are applied aerobic biological processes with different technologies, therefore the volume of sludge generated is quite large ( $\mathrm{Y}=0.4-0.6 \mathrm{~kg} \mathrm{VSS} / \mathrm{kg}$ BOD) [1]. However, most of the wastewater treatment plants don't have sludge drying equipment (original sludge humidity is from $96 \%-98 \%)$. Currently, DONRE has not selected and analyzed the statistical data on the volume and composition of the sludge and sludge volume is estimated as 200 - 300 tons/day.

This sludge usually contains mostly organic compositions (up to $60 \%$ - $70 \%$ dry weight), the concentration of toxic substances is usually undetectable or very low; therefore, this source can be used as raw materials for producing organic fertilizer (Figure 2).

Composition and volume of sludge (which is not contaminated with hazardous waste) from the urban
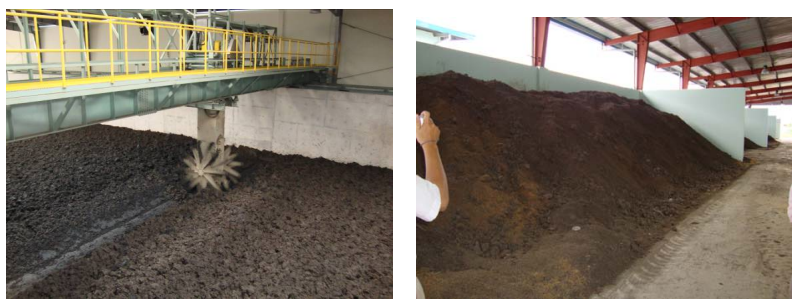

Figure 2. Sludges generated from the Binh Hung wastewater treatment $\left(141,000 \mathrm{~m}^{3} /\right.$ day) before/after treated by composting plant.

wastewater treatment plants/stations) were identified and listed in the environmental quality monitoring reports periodically of the sludge generators.

\subsubsection{Sludge from Industrial Wastewater Drainage System}

HCMC has centralized 13 industrial zones, 03 export processing zones, 01 high-tech park, and 30 industrial clusters, as well as 2000 large factories (capital investment is higher than US $\$ 10$ billion and the average number of workers is more than 300 people) and 12,000 manufacturing facilities. All industrial zones, export processing zones, high-tech parks, and large factories have installed the industrial wastewater treatment plants. Composition and volume of sludge generated from the industrial wastewater treatment plant of industrial facilities are periodically reported 2 times/year in the environmental reports, hazardous waste management reports, etc. The volume of sludge generation is about $300-400 \mathrm{~m}^{3} /$ day with very different components. The statistical data should be analyzed and stored. Figure 3 shows an example of sludge generated from enterprise and industrial zone.

For the centralized wastewater treatment plants of industrial parks, sludge composition is rather similar to sludge generated from domestic wastewater treatment plants. For the local wastewater treatment plants, sludge composition is specific for each industrial sector and it may contain hazardous waste (heavy metals, plant protection chemicals, grease, etc.).

\subsubsection{Septic Tank Sludge}

HCMC has about 9 million people living in 1.4 million individual households (houses) and 400,000 apartments. According to building regulations, all houses (villas, individual apartments and condominiums) must build the septic tank. Frequency of sludge dredging from septic tanks is very different ranging from $1-2$ years to 5 - 10 years.

According to the actual survey data and theoretical calculations based on the population and the generation rate ( $\mathrm{kg}$ per person per day); the total volume of septic tank's sludge of HCMC is about 250 - 350 tons (wet 

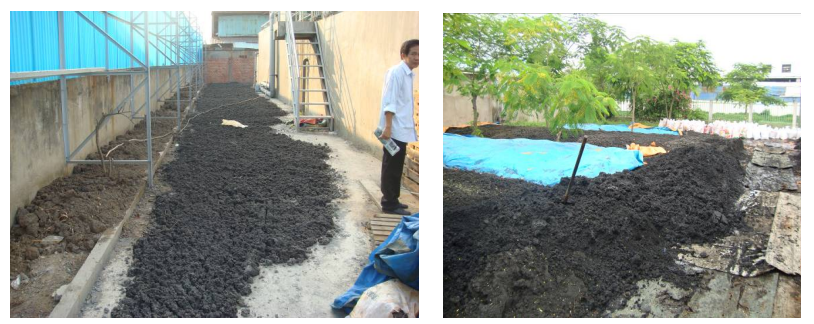

Figure 3. Sludges generated from the wastewater treatment plant of Din Ki tanneries and Le Minh Xuan Industrial Zone (4000 $\mathrm{m}^{3} /$ day).

weight)/day. Total suspended solids (TSS) of sludge rangs from $36,000 \mathrm{mg} / \mathrm{L}$ to $131,000 \mathrm{mg} / \mathrm{L}$, while organic components (volatile suspended solids-VSS) is up to $80 \%$ - $90 \%$ of the dry weight $(27,000-49,000 \mathrm{mg} / \mathrm{L})$.

However, with current sludge dredging processes (using clean water to clean and dredge), the volume of sludge transported to the centralized treatment plants will rise very large (TSS $=2 \%-3 \%$ ). Sludge concentration is high level of nitrogen compounds $\left(\mathrm{N}_{\text {total }}=1500-1800\right.$ $\mathrm{mg} / \mathrm{L}$ ). In addition, this sludge also contains a lot of different types of waste, such as paper, plastic bags, textile, etc. [2].

\subsubsection{Sludge Discharged from Water Treatment Plants}

Water consumption demand of HCMC has been provided by six water treatment plants:

1) Thu Duc water treatment plant $\left(750,000 \mathrm{~m}^{3} /\right.$ day);

2) BOO Thu Duc water treatment plant $(300,000$ $\mathrm{m}^{3}$ /day);

3) Tan Hiep water treatment plant (300,000 $\mathrm{m}^{3} /$ day);

4) Tan Phu water treatment plant $\left(75.000 \mathrm{~m}^{3} /\right.$ day);

5) Kenh Dong water treatment plant (200,000 $\mathrm{m}^{3} /$ day);

6) Binh An water treatment plant (100,000 $\mathrm{m}^{3} /$ day).

Excepting Tan Phu water treatment plant used underground water, all water treatment plants use surface water sources. Many types of aluminum sulphate and lime or soda are the flocculation chemical and alkaline used in water treatment plants. Composition and volume of sludge from the city's water treatment plants were studied and presented by CDM company (USA) and Department of Science \& Technology through these detailed reports (2010). Volume of sludge generated from the water treatment plant is presented in Table 1. Figure 4 shows how sludge reservoir from water treatment plant of BOO Thu Duc water treatment plant and Tan Hiep water treatment plant look like.

\subsubsection{Sludge from Canal Dredging and from Construction Site}

According to the classification, a part (57 km length) of the city's canal system (total length is $1240 \mathrm{~km}$ ) is a drainage network of level 1 with the functions to receive
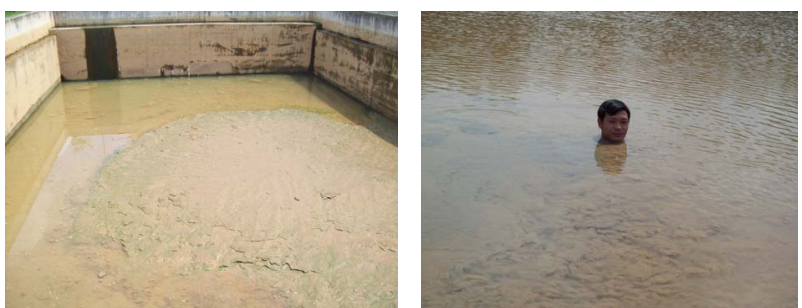

Figure 4. Sludge reservoir from water treatment plant of BOO Thu Duc water treatment plant and Tan Hiep water treatment plant.

Table 1. Waste discharge amount from water treatment plants (kg DS/day) [3].

\begin{tabular}{ccccc}
\hline $\begin{array}{c}\text { Water treatment } \\
\text { plant }\end{array}$ & Minimun & Average & Maximun & Remarks \\
\hline Thu Duc & 9.861 & 40.737 & 135.118 & Surface water \\
BOO Thu Duc & 3.776 & 15.312 & 52.312 & Surface water \\
Tan Hiep & 10.932 & 18.470 & 54.858 & Surface water \\
Tan Phu & 2.449 & 3.321 & 4.158 & Gound water \\
Kenh Dong & - & - & - & Surface water \\
Binh An & 1.233 & 5.104 & 16.712 & Surface water \\
\hline
\end{tabular}

the discharges of wastewater from the gates of generators and rainwater from basins. Sludge composition from canal dredging activities was also presented in some previous studies, but these data are insufficient and noncontinuous. The sludge composition changes based on time, wastewater types, the receiving canals, and dredging depth. The data analysis showed that the largest component is sand and soil (30\%-70\%), the surface layer $(30-50 \mathrm{~cm})$ with a high pollution, the bottom layer is soil and clay. Sludge volume of canal dredging is up to $1750 \mathrm{~m}^{3}$ per day and will increase following the environmental improvement projects (Nhieu Loc-Thi Nghe canals, Tau Hu-Ben Nghe cancals, Doi-Kenh Te canals, Tan Hoa-Ong Buong-Lo Gom canals, Tham Luong-Ben Cat-Vam Thuat canals), the renovation and expended projects (Xom Cui canal-250,000 $\mathrm{m}^{3}$, Xuyen Tam canal$300,000 \mathrm{~m}^{3}$, Chiet canal-Trau Trau-Tac river $-538,000$ $\mathrm{m}^{3}$, Giong Ong To canal-550,000 $\left.\mathrm{m}^{3}\right)$, the construction and infrastructure projects (Saigon river tunnel, metro, underground bridges, etc.) up to millions of $\mathrm{m}^{3}$. This can be reused as backfill material (leveling) for the new urban area (Thu Thiem, Northwest of $\mathrm{Cu}$ Chi, Hiep Phuoc, etc.). This basic data should be updated and analyzed.

Sludge from the construction sites is different nature with other types of sludge (predicted) but there are currently no specific figures. 


\subsection{Collection, Transportation, Reuse, Recycling and Treatment}

Currently, only sludges generated from sewage dredging, canal dredging, and septic tank are transported by trucks and barges (sludge from canal dredging).

The UDC and the public service limited company of districts are responsible for the collection and transportation of sludges. Transportation vehicles (no data on the number of vehicles) have capacity from 4 to 10 tons/(8 $18 \mathrm{~m}^{3} /$ vehicle) (Figure 1). Transportation route is unknown depending on the driver, sludge disposal location, and the traffic situation at the transportation time. Barges (300 - 500 tons/barge) is often used to transport dredged canal sludge. These barge teams are sellected by bidding process for dredging contracts.

Previously, the total amount of collected sludge from the urban wastewater drainage system is transported and dumped on Dong Thanh landfill site (District 12). For recent years (after the Dong Thanh landfill site was closed in 2003), this sludge could not determine the disposal place for spills. The UDC was tasked to prepare the investment project "Construction of receiving stations, sludge processing and handling at Da Phuoc, capacity: $3000 \mathrm{~m}^{3} /$ day”. This project accounts 42.02 hectares in the Da Phuoc waste treatment complex (Binh Chanh) from many years ago (since 2008) by City People's Committee. The report of investment project has been completed and transferred to DONRE for consideration since 2009, but so far the project has not been implemented by a number of objective and subjective reasons.

Sludge from domestic wastewater treatment plants of condominiums, restaurants, hotels, etc. after dehydration (drying) is disposed with municipal solid waste (illegal) and transported to the sanitary landfill sites or disposed in "unknown" place or a very small part is used for processing composting. Only sludge from the centralized domestic wastewater treatment plants is processed for recycling into compost. However, composting processing technology of Japan applied at the Binh Hung factory (sludge mixed with straw and compost) by aerobic composting by mixing process (Figure 2) which is not completed causing of heavy stench for environment surroundings. DONRE has proposed treatment plan in conjunction with the organic component of the municipal solid waste to produce compost.

Sludge from industrial wastewater drainage system is collected, transpoted, and treated by the proper legal companies which have handling functions to collect, transport and treatment via contract with investment companies and industrial park's business or factory owners/production facilities. Hazardous sludge is treated by solidification of fly ash after burning. However, a significant amount of industrial waste sludge (not statistically) is disposed into municipal solid waste to reduce solid waste disposal costs.

Sludge from septic tank will be collected and transported by special vehicles (150 - 164 trucks) of 3-5 tons/truck (with a capacity of $3-5 \mathrm{~m}^{3} /$ truck) (Figure 5). Currently, the entire collection of sludge from septic tank are handled by mechanical methods combined aerobic biological (natural) and products used as raw materials for the production of organic fertilizer at Hoa Binh sludge treatment plant (located at Da Phuoc waste treatment complex and cemeteries-Binh Chanh District). This is a septic sludge treatment plant of the city and is the first investment by the private sector (100\% socialization) both in terms of capital investment and handling charges. So, when the volume of collected sludge not enough for the treatment facility's capacity, less than design capacity, several processing steps have been ignored to reduce costs.

DONRE has proposed sludge treatment options associated with compostable municipal solid waste (excess food) to compost to offset capital and operating costs. This is lesson for $100 \%$ socialization works of the waste treatment projects and lessons learned about the coordination between the administrative bodies of state management and the implementing companies (management tools).

Sludge from the water treatment plant is discharged directly into water sources (Thu Duc water treatment plant) or stored in the reservoir to handle (the remaining water treatment plants). Once stored in the reservoir to remove water, sludge is transported to dispose at "unknown” locations.

Sludge from the construction sites are collected, transported, and disposed at Dong Thanh landfill site (before 2007) and the "unknown" location (at present). Thus, except for the sludge from septic tank processed and used as fertilizer, other types of sludge are pre-treated or not treated and discharged directly into landfill sites or "not defined" locations with very low recycling rate.

A major problem is currently not scheduled for any city funds to handle the sludge generated from public services (sludge from wastewater drainage system, sludge from canal dredging). Therefore, sludge is usually
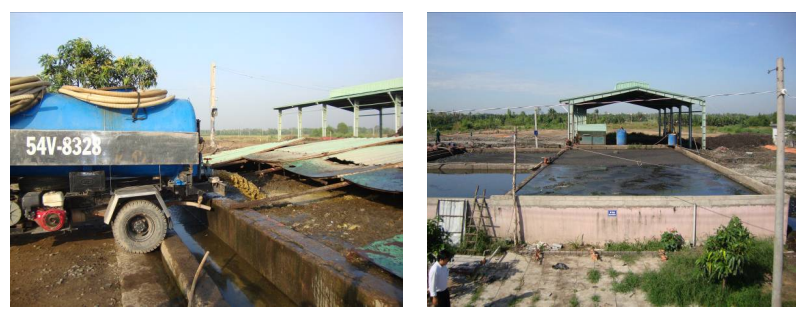

Figure 5. Transportation and treatment facilities (producing compost fertilizer) of sludge generated from septic tanks at Hoa Binh plant (Da Phuoc Waste treatment complexBinh Chanh). 
"open dumping” for the lowest treatment cost without treatment. Estimated cost of the sludge treatment is approximately 300,000 VND/ton and a round 1000 billion VND/year, even higher.

\subsection{State Administration System}

Previously, sludge from urban wastewater drainage system is responsible for managing by UDC and the public service limited company at districts. Sludge from water treatment system is responsible for managing by Saigon water supply Corporation (SAWACO) under the Department of Transportation. Sludge from the construction is responsible for managing by the Department of Construction, while sludge from septic tanks is responsible for managing by the Department of Transportation. Since the public service companies were transformed into one member limited liability company, the responsibility of these companies have been not assigned. However, due to the sense of responsibility, DONRE (Solid waste management division) is responsible for the management of these sludges (excepting sludges from water treatment plants), but they are lacking official experts, policy, and technical support facilities. In 2012, the decentralization of the state administration for sludge management assigned officially to DONRE.

\section{Orientation Plan}

To be able to manage all kinds of sludge, reduce environmental pollution to a minimum, re-use of sludge in different purposes at the highest level, DONRE has developed the overall direction plan of solid waste management system in HCMC until 2020 and vision to 2030, towards green growth, low-carbon emission, and sustainable development; including the different types of sludge [4].

\subsection{Location of Sludge Recycling and Processing Facilities}

The sludge recycling and treatment complex (42.02 ha) planed for treating by UDC as investors at the Da Phuoc solid waste treatment complex and Cemetery (Binh Chanh). To get some ideas about reducing the distance transportation in the city, DONRE will continue to plan the sludge recycling and treatment complex at the North-West solid waste treatment complex (Cu Chi) and can add 1 - 2 more complexes in the city's boundary or the Thu Thua solid waste treatment complex (Long An).

\subsection{Treatment and Recycling Technology}

The most appropriate and modern technology towards of the highest recycling will be applied in these complexes. The inorganic materials (sand, clay, soil) will be recycled as building materials or filling/leveling. The biodegradable materials will be used for generating renewable energy or producing organic fertilizer (compost). Some recuse and treatment technologies (mechanical, chemical, physical and biological) are proposed to apply in projects of UDC [5].

\subsection{Capital and Operating Costs}

DONRE is calling for investors from different financial sources with the goal of socialization for sludge treatment and reuse activities. The most appropriate investment plan is BOO (Build-Operation-Own) and the city will pay the treatment costs (capital and operating costs) for investors based on different sludges, such as sudge from the public (public services), sludge from urban/ domestic wastewater drainage system (1), sludge from water treatment plant (5), and sludge from the construction of infrastructure and public utilities (roads, bridges, metro, etc.) and charges for service users.

Other sludge treatment costs are paid by the sludge generator according to the principle of "service beneficiaries have to pay service providers". This is a difficult problem in calculating investment and payback period due to unstable source emissions and ability treatment fee collection [4].

\subsection{Management Policy}

This is an important factor, even determining the success or failure of the investment project and the management of the successful administration of sludges. To encourage and ensure the investment, the following legal documents and state administrative management system will have to be built:

- Building regulations for managing sludge in the city;

- Developing policies and incentives to encourage the sludge treatment and recycling facilities;

- Constructing unit price for sludge treatment fee;

- Applying information technology to manage transportation routes and data management;

- Organizing (structure of administrative organization) and building coordination regulations between state management administrative bodies;

- Organizing the inspection system, monitoring and sanctioning.

Besides, DONRE is actively training staff to reach the profesional level, constructing technical basis, and applying information technology for managing this waste effectively. And an issue that needs special attention is the state management administrative agencies should change their perceptions about business sectors and the business is identified as "tool" to carry out the state's management process, for example: to produce a product, they must have "productivity tool". Moreover, "the State 
is never stronger and wisdom more than business”.

\section{Conclusions}

In recent times, several (6) kinds of sludges are generated from the living, manufacturing, construction, etc. activities of HCMC affecting environmental quality significantly, both in terms of environmental pollution (physical, chemical, biological) and landscape.

Large volume (3000 - $4000 \mathrm{~m}^{3} /$ day, equivalent to 5000 6000 tons/day and millions of tons/year for coming years), diverse compositions, and scattered location are in many places; therefore, the collection, transport, treatment and reuse are rather difficult and complex. All most sludges are dumped into landfill sites or the "unknown" locations, although most of the sludges in varying degrees are still worth using.

The state administrative management system of the city has not kept pace with the demands of the actual development in the field of sludges for many reasons, objective and subjective, but the major reason is mainly the lack of human, material and financial resources. The result is lack of legal documents for the management, lack of investment incentives, etc.

To support for green growth targets, low carbon emissions and sustainable development, HCMC should immediately implement the management actions for various types of sludges towards the highest reuse.

\section{Remarks}

Sludge is a mixture of solids and water that have moisture content greater than $70 \%$ and particle size of less than $2 \mathrm{~mm}$. Legal documents should clarify the concept: 1) disposal sludge; 2) recyclable sludge; 3) sludge is used as raw materials for production, etc.

\section{REFERENCES}

[1] Metcalf \& Eddy, "Wastewater Engineering: Treatment and Reuse," McGraw Hill, New York, 2004.

[2] N. T. Vietm, et al., CENTEMA, "Survey the Status of Septic Sludge Collection, Transportation and Treatment in Ho Chi Minh City: Studying and Proposing Management Mechanism,” Research Report of Department of Science and Technology of Ho Chi Minh City, 2008.

[3] CDM, "Water Supply Sludge Treatment for HCMC," Report for Ho Chi Minh City, 2010.

[4] DONRE, "Master Plan (Oriented Strategy) the Waste Management System in Ho Chi Minh City by 2020, Vision to 2030, Driven to the Green Management System,” 2011.

[5] UDC, "Construction Da Phuoc Plant of Receiving, Processing and Treatment of Sludge, Capacity of $3000 \mathrm{~m} / \mathrm{ngd}$," Investment Report, 2011. 